\title{
Distribution and habitat use patterns of benthic decapod crustaceans in shallow waters: a comparative approach
}

\author{
A. Pallas ${ }^{1}$, B. Garcia-Calvo ${ }^{1}$, A. Corgos $^{1}$, C. Bernardez ${ }^{2}$, J. Freire ${ }^{1, *}$ \\ ${ }^{1}$ Departamento de Biologia Animal, Biologia Vegetal y Ecologia, Universidad de A Coruña, Campus de A Zapateira s/n, \\ A Coruña 15071, Spain \\ ${ }^{2}$ Centro de Ecologia Costera, Centro Universitario de la Costa Sur, Universidad de Guadalajara, V. Gomez Farias 82, \\ San Patricio-Melaque, Jalisco 48980, Mexico
}

\begin{abstract}
Coastal areas are widely considered to be nurseries for many marine species. New approaches to this concept take into account interactions among environmental variables and ecological variation related to geographical location, as well as the complex life cycles of marine invertebrates. We present a comparative approach to assessing the association between environmental variables and patterns of distribution and the habitat use of benthic decapod species in coastal areas. Through this approach we infer which processes underlie these patterns and identify appropriate habitat-use models. An intensive fine-grain sampling design was used to account for environmental gradients occurring at different spatial scales (defined by substrate type, depth, exposure and geographical location) in a temperate oceanic bay (Ria de A Coruña, NW Spain). A high proportion of juveniles occurred in most populations, but our results did not allow us to generally designate coastal areas as nurseries, except for a few species, which showed marked spatial segregation between juveniles and adults. Coastal habitats are predominantly used as nurseries by juveniles of larger species, while, for smaller decapods, they seem to constitute habitats for the entire population. Larval transport may account for mesoscale distribution patterns, while microscale distribution may respond to the complex interaction among different processes, i.e. habitat selection at settlement, differential mortality among habitats, post-settlement dispersal and ontogenetic habitat shifts. Sandy substrates were characterised by low-diversity communities dominated by hermit crabs. In rocky bottom communities, variability in spatial patterns was mostly related to substrate type and geographical location. Caridean shrimps had higher densities on flat rock surfaces, with similar juvenile and adult patterns. Anomuran species occurred mainly on cobbles. Distribution patterns of brachyurans varied among species, but did not change greatly from juveniles to adults.
\end{abstract}

KEY WORDS: Spatial scale $\cdot$ Nursery habitat $\cdot$ Habitat selection $\cdot$ Settlement $\cdot$ Decapod crustaceans · Coastal ecosystems $\cdot$ Habitat use $\cdot$ Distribution $\cdot$ Ria de A Coruña

Resale or republication not permitted without written consent of the publisher

\section{INTRODUCTION}

Coastal areas are widely considered to be nursery habitats for many marine vertebrate and invertebrate species. Traditionally, nursery habitats have been defined as areas where juveniles occur at higher densities, avoid predation more successfully, or grow faster than in other habitats (see review in Gillanders et al. 2003). Beck et al. (2001) proposed a more accurate definition, which includes the relative contribution of each potential nursery habitat to the adult population. Furthermore, new approaches apply this concept, not to an entire area, but to a specific habitat defined by the complex interaction of environmental variables and ecological functions related to local variation (Beck et al. 2001, Stoner 2003). So far, this concept has 
only been studied for a few fish and invertebrate species and in a limited number of ecosystem types (e.g. mangroves, coral reefs, estuaries) (Beck et al. 2001, Gillanders et al. 2003). Life histories of benthic invertebrates are different from those of fish, and are typified by complex life cycles, with pelagic phases that carry out medium- or large-scale dispersion and benthic phases characterised by limited mobility with respect to fish (Roughgarden et al. 1988). These differences, along with the high diversity of coastal habitats, which so far has been poorly described, suggest the need for further studies to produce general hypotheses and theories about patterns in use of coastal habitats by marine species.

Shallow benthic habitats are structurally complex environments where many biotic and abiotic factors (such as predation or physical disturbance, respectively) determine habitat quality and generate different stress gradients that determine community structure and population dynamics. These factors act at different spatial scales, creating gradients that can occur on the order of metres (microscale), 100s of metres or kilometres (mesoscale), or even on the order of 10 s to 100 s of kilometres (macroscale) (Orensanz \& Jamieson 1998). As a response to this variability, benthic organisms might select their habitat to minimise the trade-offs among different stress factors.

The process of habitat selection can occur in 2 phases of the life cycle. Firstly, most benthic invertebrates exhibit a certain level of active selection at larval settlement and metamorphosis (Paula et al. 2001, Van Montfrans et al. 2003) and in early benthic stages (Moksnes et al. 2003), to avoid the typical high mortality associated with this phase of the life cycle. Moreover, differential mortality among habitats also influences the final distribution patterns of juveniles (Palma et al. 1999, Robinson \& Tully 2000). Mobile invertebrates can also modify their habitat preferences in later benthic stages, either by carrying out ontogenetic habitat shifts (Pile et al. 1996, Moksnes 2004) or by differential habitat use related to different behaviours (e.g. foraging or mating).

Decapod crustaceans are a suitable group for studying the interplay of recruitment processes, habitat selection and postlarval mortality, due to their mobility, complex life cycles and population dynamics. Decapod crustaceans play a major ecological role in the dynamics of coastal benthic ecosystems, due to their abundance and high taxonomic and trophic diversity (Squires 1990, Ingle 1996, J. Freire et al. unpubl. data). Many decapods are also economically important by supporting fisheries, particularly in coastal areas (Caddy 1989, Squires 1990, Freire et al. 2002).

In the present study we applied a comparative approach to analyse the patterns of distribution and habitat use of different decapod species inhabiting coastal areas. From these patterns we tried to infer habitat-related differences in population-level processes. Intensive sampling using a fine-grained spatial design was used to account for the different environmental gradients in a coastal ecosystem at different spatial scales, and to identify nursery habitats for some of the decapod species. In addition, the relationship of different environmental variables to the spatial distribution and habitat use of decapod species was investigated.

\section{MATERIALS AND METHODS}

Sampling. A balanced design survey using random sampling was carried out in July and August 1998 along the coast of the Ria de A Coruña (NW Spain) (Fig. 1). Previous studies suggested that at temperate latitudes a settlement peak takes place during these months for many invertebrate species (Pfister 1997). The study area is a coastal embayment located off the north-western Iberian Peninsula. Its main axis is $5 \mathrm{~km}$ long, and it has a north-south orientation; the mean depth is $25 \mathrm{~m}$ in the outer zones and $10 \mathrm{~m}$ in the inner part (Cosme de Aviles \& Prego 1995). Three sites along

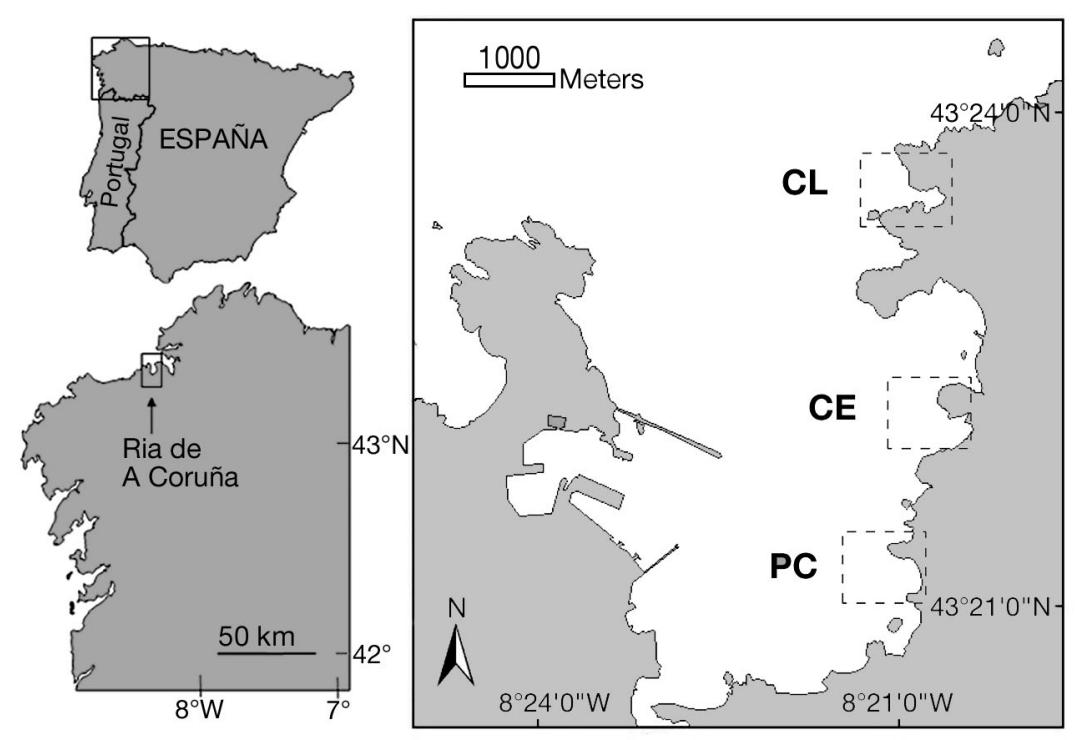

Fig. 1. Ria de A Coruña, NW Spain. Sampling sites located along its eastern coastline: Portocobo (PC), Canide (CE) and Canabal (CL) 
the eastern coastline of the ria were selected to sample the mesoscale variability (sites were separated by 1.5 to $2.5 \mathrm{~km}$ ). The western coastline has been subject to considerable urban and industrial development and was not included in this study.

An array of sampling locations was defined within each site according to the combination of 3 microscale variables:

- Wave exposure: exposed and sheltered locations (separated by 100s of metres) were selected depending on their orientation with respect to the mouth of the bay. Seaweed communities were also observed to confirm the exposure level assigned to each location.

- Depth was determined using 3 nominal strata: 0 (low intertidal), 1 (3 to $5 \mathrm{~m}$ ) and 2 (8 to $12 \mathrm{~m}$ ). Depths are indicated in relation to lowest low water. Locations at different depths within the same site and exposure were separated among them by 10 s of metres.

- Substrate type: 4 types of relevant substrate were identified in the study area: sandy bottoms, flat rock surfaces covered with small seaweeds, cobbles and boulders, and kelp Saccorhiza polyschides holdfasts. Distances among sampled substrates at a given depth were on the order of metres.

Every possible combination of factor levels (site, exposure, depth and substrate) was sampled, with 2 exceptions. Locations at Depth 2 were always considered as sheltered, assuming that the importance of the effect of the waves is significantly reduced below $8 \mathrm{~m}$ depth. Sandy bottoms appeared only in significant proportions at the most internal site, and thus they were sampled only there. Each sample consisted of 4 replicates taken consecutively on the same day. Each location was sampled only once.

A suction sampler operated by SCUBA divers was used. This device consisted of a PVC pipe $(1.70 \mathrm{~m}$ length, $7.5 \mathrm{~cm}$ inner diameter) provided with an air diffuser connected to an air compressor and fitted to a $0.5 \mathrm{~mm}$ mesh size bag. Rock surfaces, cobbles and sandy bottom samples were taken by placing $50 \times$ $50 \mathrm{~cm}$ stainless steel quadrats on the substrate and suctioning the epibenthos. Large animals (over half the diameter of the pipe) enclosed in the quadrats were collected manually. Different operation methods were employed for each substrate type. Flat rock surfaces were scraped while suctioning to separate algae and sessile organisms from the substrate. Cobbles and boulders $<7.5 \mathrm{~cm}$ diameter were suctioned, as well as the underlying sediment; larger cobbles were scraped, and sessile organisms were suctioned. Sandy bottoms were suctioned to $5 \mathrm{~cm}$ depth. Each kelp holdfast sample consisted of 4 replicates, each of which consisted of 1 holdfast, randomly chosen and pulled up manually before suctioning its content.
Samples were washed in filtered seawater and transferred to plastic bags for freezing at $-20^{\circ} \mathrm{C}$. After defrosting, decapod crustaceans were separated, fixed in a solution of $4 \%$ formaldehyde in seawater and subsequently preserved in $70 \%$ ethanol. Specimens were identified following the taxonomical keys of Hayward et al. (1995) and Gonzalez-Gurriaran \& Mendez (1986). The following biological data were recorded: sex, presence of brood in females, and body size measured as carapace length in Caridea and Paguridea and as major carapace axis in Brachyura and other Anomura (carapace width in all taxa except majids and Galathea strigosa). Carapace length measurements excluded the rostrum, except for Inachus phalangium and Macropodia rostrata. Morphometrical measurements were taken using a stereoscopic microscope for individuals $<20 \mathrm{~mm}$ and a calliper for larger specimens.

Most individuals were identified to species level, except in some cases where it was not possible due to taxonomical difficulties, especially in juvenile phases. Species of the superfamily Paguridea show allometric growth of the characters used in taxonomy (Bertini \& Fransozo 1999, Benvenuto \& Gherardi 2001), making the identification of early stages more difficult; due to the high proportion of newly settled juveniles found, these species were pooled as a single taxon. Some genera (Eualus, Hippoyte, Palaemon, Processa, Pilumnus and Xantho) were represented in the collected samples by 2 species, and differentiation between them was impossible for a high proportion of damaged or early-stage specimens; thus, these species were pooled as genera for data analyses.

Size at onset of maturity was used to estimate the abundance and relative proportions of juveniles and adults in the samples for each taxon (Table 1). Size at maturity was estimated according to the following criteria: (I) size of the smallest ovigerous female found (excluding outliers) and (II) size at maturity reported in literature. In the case of Ebalia tuberosa, no information about size at maturity was available, and the maturity stage of the 2 individuals found was not determined. Criterion I was only used when the number of ovigerous females was large (>15 individuals) or when no information about size at maturity of the species was available in the literature. When identification to species level was not possible, the minimum size at maturity estimated for the taxon was applied (Zariquiey Alvarez 1968, Williams 1984, Hayward et al. 1995, Oh \& Hartnoll 1999, Squires et al. 2000; Marine Information Network for Britain \& Ireland: www.marlin.ac.uk, Crustikon, University of Tromsø: www.tmu.uit.no/ crustikon/Decapoda/Decapoda2/Species_index.htm). 
Table 1. Abundances, mean densities (SB: sandy bottoms; RB: rocky bottoms; KP: kelp holdfasts) and adult/juvenile ratios of decapod crustacean taxa found in shallow benthic habitats of the Ria de A Coruña. The taxa in bold (relative abundance $>1 \%$ ) were used in the analyses. Species pooled as genera due to identification difficulties: Hippolyte (represented by the species $H$. varians and H. longirostris), Pilumnus (P. hirtellus, P. spinifer), Xantho (X. incisus, X. pilipes), Processa (P. edulis, P. modica), Eualus (E. occultus, E. pusiolus), Palaemon (P. longirostris, P. serratus, P. elegans), Philocheras (P. fasciatus, P. trispinosus) and Liocarcinus (L. arcuatus, L. vernalis). Sexual maturity criteria: size of smallest ovigerous female (I) and size of maturity in literature (II)

\begin{tabular}{|c|c|c|c|c|c|c|c|c|c|c|c|}
\hline \multirow[t]{2}{*}{ Taxon } & \multirow[t]{2}{*}{$\begin{array}{l}\text { No. } \\
\text { of ind. }\end{array}$} & \multirow{2}{*}{$\begin{array}{l}\text { Relative } \\
\text { abundance } \\
\quad(\%)\end{array}$} & \multicolumn{2}{|c|}{ Sexual maturity } & \multirow{2}{*}{\multicolumn{4}{|c|}{$\begin{array}{l}\text { - Mean densities } \\
\text { RB }\end{array}$}} & \multirow{2}{*}{\multicolumn{2}{|c|}{$\begin{array}{l}\mathrm{KH} \text { of adults } \\
\text { (ind. holdfast }{ }^{-1} \text { ) SD }\end{array}$}} & \multirow{2}{*}{ Proportion } \\
\hline & & & $(\mathrm{mm})$ & Criteria & (ind. $\mathrm{m}^{-2}$ & & (ind. $\mathrm{m}^{-2}$ ) & $\mathrm{SD}$ & & & \\
\hline \multicolumn{12}{|l|}{ Caridea } \\
\hline Athanas nitescens & 1432 & 16.19 & 2.8 & I & 2.33 & 6.92 & 44.04 & 102.09 & 9.87 & 19.80 & 0.15 \\
\hline Hippolyte spp. & 936 & 10.58 & 1.7 & I & 0.33 & 1.15 & 31.96 & 38.46 & 4.90 & 6.55 & 0.36 \\
\hline Thoralus cranchii & 929 & 10.51 & 1.4 & I & 0.33 & 1.15 & 32.54 & 50.08 & 5.24 & 8.31 & 0.70 \\
\hline Processa spp. & 230 & 2.60 & 5.8 & I & 0.33 & 1.15 & 9 & 12.08 & 0.29 & 0.84 & 0.08 \\
\hline Eualus spp. & 105 & 1.19 & 1.8 & I & $\mathbf{0}$ & $\mathbf{0}$ & 4.38 & 12.16 & $\mathbf{0}$ & $\mathbf{0}$ & 0.33 \\
\hline Palaemon spp. & 102 & 1.15 & 10 & II & 0.67 & 2.31 & 4.08 & 22.46 & 0.06 & 0.34 & $\mathbf{0}$ \\
\hline Philocheras spp. & 53 & 0.60 & 3.5 & I & 2 & 4.67 & 1.88 & 4.02 & 0.05 & 0.27 & 0.02 \\
\hline Alpheus macrocheles & 28 & 0.32 & 4.5 & I & 0 & 0 & 1.17 & 3.07 & 0 & 0 & 0.29 \\
\hline \multicolumn{12}{|l|}{ Brachyura } \\
\hline Pilumnus spp. & 713 & 8.06 & 7 & II & $\mathbf{0}$ & $\mathbf{0}$ & 21.38 & 34.30 & 6.69 & 6.72 & 0.18 \\
\hline Xantho spp. & 316 & 3.57 & 9 & II & $\mathbf{0}$ & $\mathbf{0}$ & 12.63 & 21.63 & 0.27 & 0.70 & 0.39 \\
\hline Pirimela denticulata & 106 & 1.20 & 11.3 & I & $\mathbf{0}$ & $\mathbf{0}$ & 4.08 & 10.72 & 0.15 & 0.56 & 0.10 \\
\hline Necora puber & 49 & 0.55 & 49.8 & II & 0 & 0 & 1.67 & 3.16 & 0.16 & 0.42 & 0 \\
\hline Inachus phalangium & 13 & 0.15 & 9.8 & II & 0 & 0 & 0.38 & 1.17 & 0.08 & 0.35 & 0.54 \\
\hline Macropodia rostrata & 11 & 0.12 & 13.9 & I & 0 & 0 & 0.46 & 1.52 & 0 & 0 & 0.09 \\
\hline Liocarcinus spp. & 8 & 0.09 & 25 & II & 0.67 & 1.56 & 0.25 & 1.13 & 0 & 0 & 0 \\
\hline Pisa tetraodon & 7 & 0.08 & 21.2 & II & 0 & 0 & 0.29 & 1.05 & 0 & 0 & 0.29 \\
\hline Cancer pagurus & 5 & 0.06 & 127 & II & 0 & 0 & 0.17 & 1.29 & 0.02 & 0.10 & 0 \\
\hline Achaeus gracilis & 4 & 0.05 & 5.8 & II & 0 & 0 & 0.17 & 0.99 & 0 & 0 & 0.75 \\
\hline Achaeus cranchii & 3 & 0.03 & 5.8 & II & 0 & 0 & 0.13 & 0.91 & 0 & 0 & 0.67 \\
\hline Maja brachydactyla & 3 & 0.03 & 120 & II & 0 & 0 & 0.13 & 0.70 & 0 & 0 & 0 \\
\hline Ebalia tuberosa & 2 & 0.02 & - & - & 0 & 0 & 0.08 & 0.57 & 0 & 0 & - \\
\hline Eurynome aspera & 2 & 0.02 & 8 & II & 0 & 0 & 0.08 & 0.57 & 0 & 0 & 0 \\
\hline \multicolumn{12}{|l|}{ Anomura } \\
\hline Paguridea & 1942 & 21.96 & 1.2 & I & 434.33 & 614.65 & 24.75 & 37.45 & 0.76 & 2.19 & 0.21 \\
\hline Pisidia longicornis & 1568 & 17.73 & 2.8 & $\mathbf{I}$ & $\mathbf{0}$ & $\mathbf{0}$ & 60.71 & 118.17 & 3.33 & 4.49 & 0.50 \\
\hline Porcellana platycheles & S 102 & 1.15 & 7 & $\mathbf{I}$ & $\mathbf{0}$ & $\mathbf{0}$ & 4.17 & 13.21 & 0.02 & 0.10 & 0.15 \\
\hline Galathea strigosa & 92 & 1.04 & 34.6 & II & $\mathbf{0}$ & $\mathbf{0}$ & 2.96 & 6.95 & 0.32 & 0.94 & $\mathbf{0}$ \\
\hline Unidentified & 82 & 0.93 & - & - & 0 & 0 & 2.96 & 5.17 & 0.45 & 1.07 & - \\
\hline Total & 8843 & & & & 441 & 613.24 & 266.46 & 239.46 & 32.66 & 34.99 & 0.32 \\
\hline
\end{tabular}

Data analysis. Mean densities of each species were calculated from the 4 replicates from each location. Density was expressed as the number of individuals per square metre for cobbles, flat rock surfaces and sandy bottom substrates. A linear regression analysis was performed to test the correlation between holdfast size (estimated as dry weight) and number of individuals. Since the correlation was significant $(p<0.001$; Fig. 2), densities in kelp holdfast samples were standardised to the average holdfast weight (11.68 g).

Given the different anatomical and behavioural adaptations observed in different infraorders (with swimming caridean shrimps being mainly swimming and brachyuran and anomuran crabs being bottom dwelling) and the wide range of body sizes of the sampled species, the effects of infraorder, size at maturity (a proxy of body size) and the interaction between them on the proportion of adults were tested on logtransformed data using general linear models (GLM).

GLM was employed to determine the quantitative effect of the environmental conditions (related to site, exposure, depth and substrate) on the spatial patterns of the postlarval populations. The best subsets procedure using the Akaike Information Criterion (AIC) was used to select the best model, and a normal error and identity link were assumed. Juvenile and adult densities were analysed using GLMs. Rare taxa (those that constituted $<1 \%$ of the total abundance) were excluded from the analyses. Due to the different density units used for holdfasts, analyses were performed separately for this habitat. Sandy bottom samples were also excluded from the GLM models, given the completely different specific composition and structure of the communities found and the absence of this habitat 


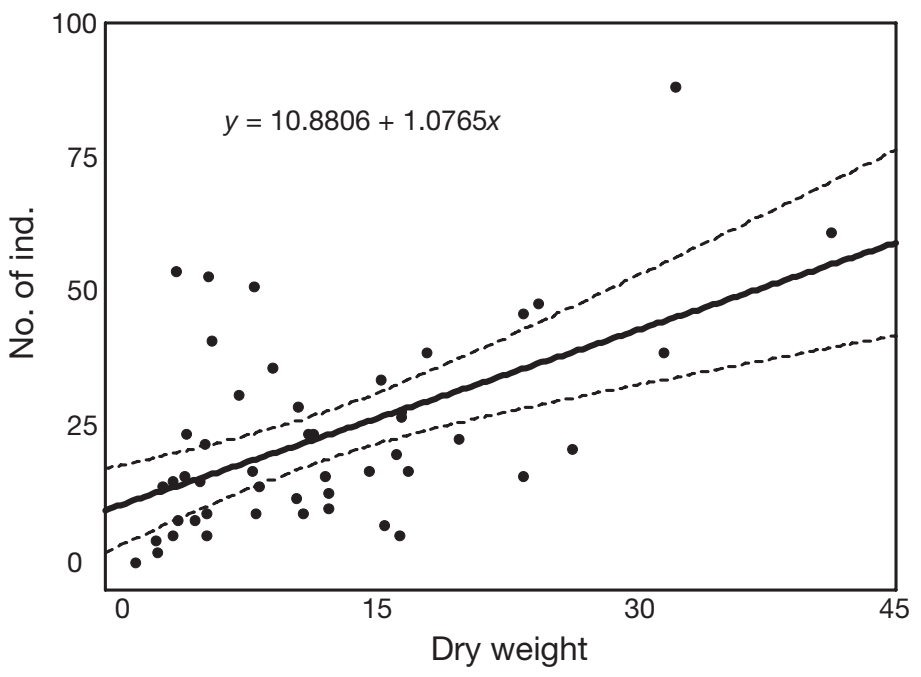

Fig. 2. Relationship between dry weight of holdfasts and number of individuals. Dashed lines represent 95\% confidence interval

at the 2 most external sites. Statistical models for rocky bottoms were fitted both for the complete data set and for flat rock surfaces and cobbles separately.

\section{RESULTS}

A total of 8843 individuals occurred in the samples, with 34 species represented, as well as the superfamily Paguridea, which was not identified to species level. The size-frequency distribution of each infraorder showed a pronounced dominance of smaller size classes, indicating a high proportion of first juvenile instars (Fig. 3). There was a significant negative effect of size-at-maturity on the proportion of adults (Fig. 4), but no effects of taxon or the interaction of both factors ( $p>0.05)$.

Juveniles of all taxa were found in the sampled area, whereas in 7 taxa adults were absent. The total proportion of adults was low (32\%), with only few species $>50 \%$ (Thoralus cranchii, Inachus phalangium and the species of the genus Achaeus) (Table 1). While the total proportion of adults of the superfamily Paguridea was low (21\%), it reached $63 \%$ in rocky bottom habitats. The following results are given only for the most abundant taxa (those that constituted $>1 \%$ of the total abundance).

\section{Sandy substrate}

Sandy and rocky bottoms had different assemblages. In sandy substrates there was low species diversity and dominance by species of the superfamily Paguridea (families Paguridae and Diogenidae). Pagurids showed
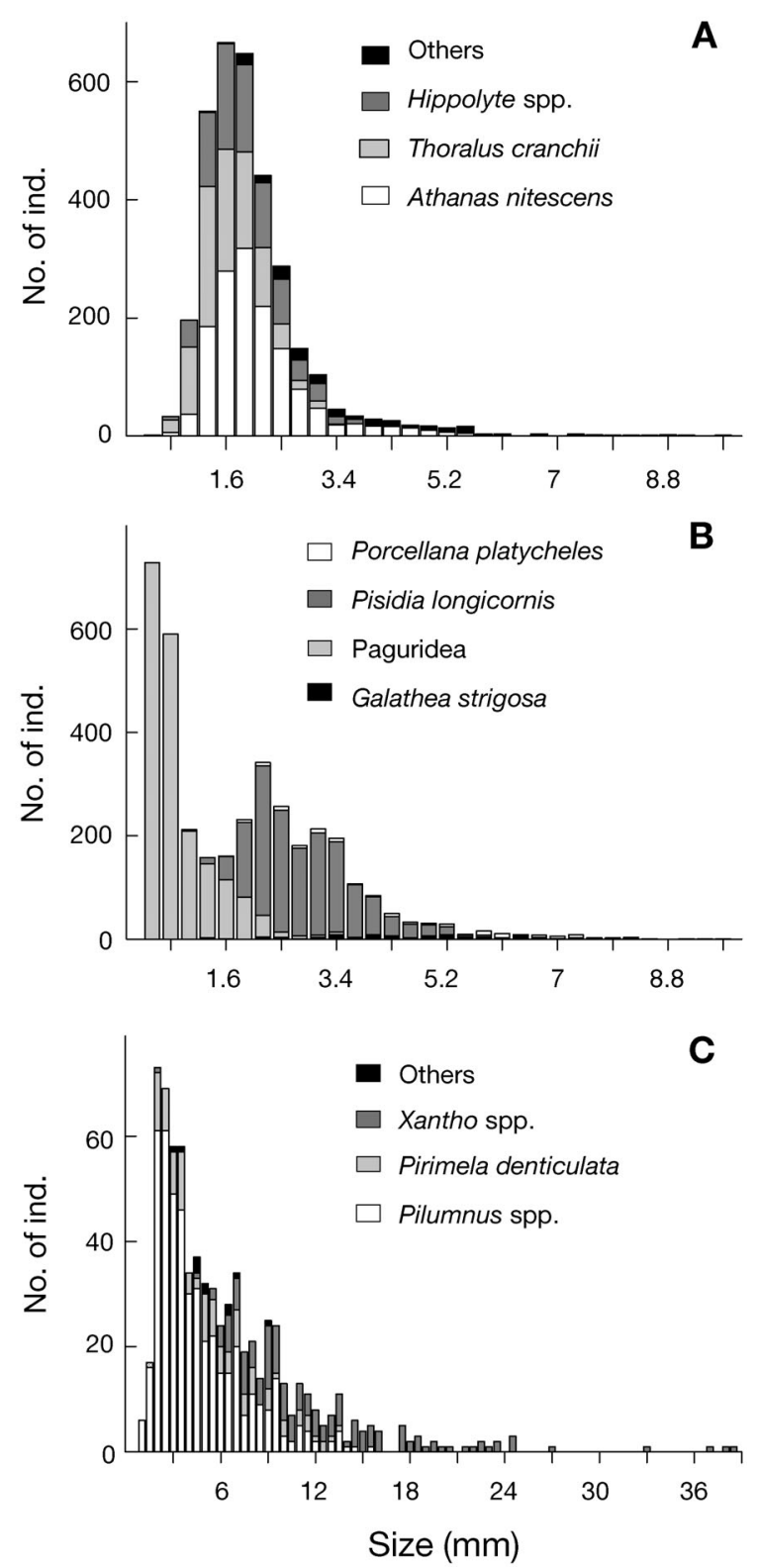

Fig. 3. Size-frequency distribution of decapod crustaceans found in the samples: (A) Caridea, (B) Anomura and

(C) Brachyura. Note different size ranges in Brachyura

very high densities (mean: 434 ind. $\mathrm{m}^{-2}$; Table 1), reaching 1227 ind. $\mathrm{m}^{-2}$ in the deepest areas (Fig. 5). Populations were composed almost exclusively of newly settled individuals, with $98 \%$ under $2 \mathrm{~mm}$ carapace length (Fig. 3). Other species appeared occasionally at very low densities (Fig. 5).

\section{Rocky substrates (cobbles and flat rock surfaces)}

Although all the independent variables had a significant effect on the distribution of decapod species, 


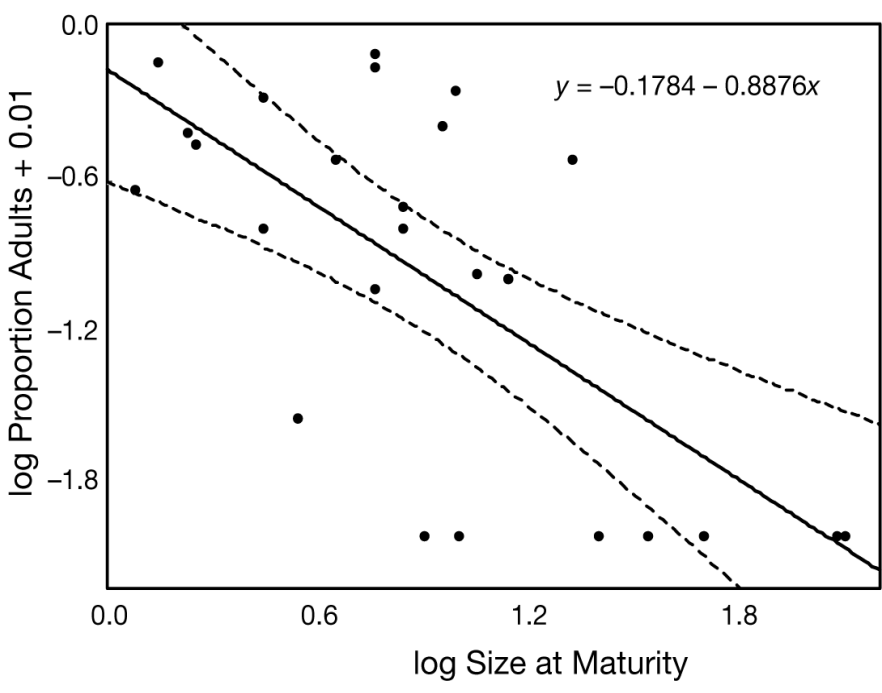

Fig. 4. Relationship between log-transformed size-at-maturity and proportion of adults for all the species found. Dashed lines represent $95 \%$ confidence interval

variability in spatial patterns for most taxa was mainly related to substrate type and sampling site (Table 2). The effects of depth and wave exposure on spatial distribution of postlarvae were not as substantial. Patterns were similar for juveniles and adults on rocky bottoms (Table 2). In both cases, substrate type was included in most of the models (85\% for juveniles, $73 \%$ for adults), while wave exposure had a lower percentage of occurrence in models for juveniles (62\%) and adults (45\%). Sampling site was also included in the same proportion of models as substrate type for juveniles.

Differential habitat use regarding substrate type was observed among species, and the effect of the other environmental variables differed by substrate type. For rocky bottoms, juveniles had higher densities at the external sampling site, except for Athanas nitescens and Thoralus cranchii, which occurred at similar densities at the internal site. Generally, the proportion of adults was lower in deeper zones, while the effect of wave exposure was variable among species. Spatial differences in distribution were more pronounced for juveniles than for adults, which were more evenly distributed among the different habitats. Since patterns varied considerably among infraorders and seemed to show consistent traits within them, we present the results separately for each infraorder.

\section{Caridea}

Caridean shrimps had higher densities on flat rock surfaces. Mean densities on flat rock samples were higher than those on cobbles, except for Atha- nas nitescens and Eualus spp., which occurred on cobbles at higher densities. Vertical distribution of juveniles varied among species, occurring from low intertidal (genera Palaemon and Processa) to 8-10 m (A. nitescens, Eualus spp. and Hippolyte spp.). Although differences due to exposure level were not significant, most caridean juveniles occurred preferentially in sheltered zones (A. nitescens, Processa spp. and Eualus spp.), except for Thoralus cranchii, which was more abundant in exposed areas (Table 2, Appendix 1; available at www.int-res.com/articles/suppl/ m324p173_app.pdf). In most carideans, adult distributions followed similar patterns to those of juveniles, although densities were generally lower. However, differences among habitats in adult densities were significant, but less remarkable, and their distribution range was wider, especially regarding exposure level and depth (A. nitescens). Differences were non-significant only for adults of Processa spp. $(p=0.317$ ) (Table 2, Fig. 4). Adults of some of the taxa also occurred at internal sites (genera Eualus and Hippolyte). In contrast, T. cranchii showed higher densities of adults than of juveniles, with a similar distribution among habitats. This trend was consistent in all habitats (Appendix 1).

\section{Brachyura}

The distribution of brachyuran juveniles was mainly determined by substrate type, although with

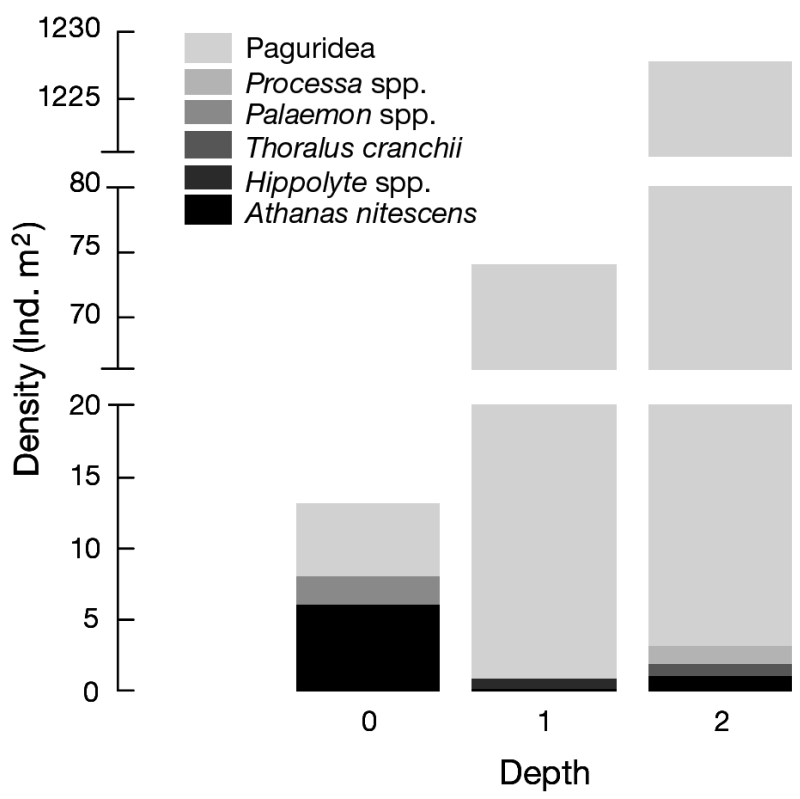

Fig. 5. Densities of taxa found in each depth stratum (0: low intertidal; 1 : 3 to $5 \mathrm{~m}$; 2: 8 to $12 \mathrm{~m}$ ) on sandy substrate. Note scale breaks in the density axis 
Table 2. Results of GLM fitted to the distribution of the most abundant species of decapod crustaceans on shallow rocky bottoms in the Ria de A Coruña. Values estimated for the different levels of the variables are relative to the missing level of each one, considered as 0 level. Variables included (Incl.) in the most parsimonious models are indicated with asterisks. Percentage of models in which a variable has been included is shown; p-values indicate the significance of the most parsimonious model for each species

\begin{tabular}{|c|c|c|c|c|c|c|c|c|c|c|c|c|}
\hline \multirow[t]{3}{*}{ Species } & \multirow[t]{3}{*}{ Intercept } & \multicolumn{6}{|c|}{ Mesoscale } & \multicolumn{4}{|c|}{ Microscale } & \multirow{3}{*}{ ) } \\
\hline & & \multicolumn{3}{|c|}{ Sampling station (km) } & \multirow{2}{*}{\multicolumn{3}{|c|}{$\begin{array}{l}\text { Wave exposure }(100 \mathrm{~s} \mathrm{~m}) \\
\text { Incl. Sheltered Incl. }\end{array}$}} & \multicolumn{2}{|c|}{ Depth (10s m) } & \multirow{2}{*}{\multicolumn{2}{|c|}{$\begin{array}{l}\text { Microhabitat }(\mathrm{m}) \\
\text { Incl. Cobbles }\end{array}$}} & \\
\hline & & Incl. & Canide & Canabal & & & & 0 & 1 & & & \\
\hline \multicolumn{13}{|l|}{ Juveniles } \\
\hline \multicolumn{13}{|l|}{ Caridea } \\
\hline Athanas nitescens & 12.00 & * & -7.33 & 2.77 & & 1.20 & & 3.67 & -2.76 & * & 8.24 & $<0.001$ \\
\hline Eualus spp. & 0.98 & $*$ & 0.59 & 0.08 & & 0.01 & * & -0.78 & -0.77 & * & 0.39 & $<0.001$ \\
\hline Hippolyte spp. & 4.85 & $*$ & -2.51 & 3.46 & * & 1.06 & * & -1.49 & -1.60 & * & -1.67 & $<0.001$ \\
\hline Palaemon spp. & 0.36 & $*$ & -0.93 & 2.21 & $*$ & 1.29 & $*$ & 2.20 & -0.56 & & -0.65 & 0.004 \\
\hline Processa spp. & 1.28 & & -0.07 & 0.15 & * & 0.91 & * & -0.45 & 1.14 & * & -1.05 & $<0.001$ \\
\hline Thoralus cranchii & 3.06 & & -0.39 & -0.33 & $*$ & -1.59 & $*$ & -2.30 & 0.92 & & -0.50 & $<0.001$ \\
\hline \multicolumn{13}{|l|}{ Brachyura } \\
\hline Pilumnus spp. & 4.92 & * & 0.36 & 1.55 & * & -2.66 & * & -1.79 & 1.80 & * & -2.14 & $<0.001$ \\
\hline Pirimela denticulata & 0.43 & * & -0.34 & 1.11 & * & 0.81 & * & 1.04 & -0.17 & * & -0.57 & $<0.001$ \\
\hline Xantho spp. & 2.99 & * & 0.11 & 1.30 & & -0.57 & & -0.41 & -0.42 & * & 2.48 & $<0.001$ \\
\hline \multicolumn{13}{|l|}{ Anomura } \\
\hline Galathea strigosa & 1.14 & * & -0.02 & 0.60 & * & -0.38 & * & -0.52 & 0.07 & * & 0.77 & $<0.001$ \\
\hline Paguridae & 3.16 & * & -1.20 & 2.75 & & 0.06 & * & -2.00 & -1.16 & * & 1.47 & $<0.001$ \\
\hline Pisidia longicornis & 11.70 & * & 6.40 & -1.20 & * & -7.14 & * & -7.79 & 1.31 & * & 4.38 & $<0.001$ \\
\hline Porcellana platychele & es 1.02 & $*$ & -0.77 & 1.73 & & 0.39 & & 0.03 & 0.46 & * & 1.11 & $<0.001$ \\
\hline (Percent) & & $(84.6)$ & & & $(61.5)$ & & $(76.9)$ & & & $(84.6)$ & & \\
\hline \multicolumn{13}{|l|}{ Adults } \\
\hline \multicolumn{13}{|l|}{ Caridea } \\
\hline Athanas nitescens & 1.22 & * & -0.89 & -0.22 & & 0.20 & * & 1.21 & -0.17 & * & 0.88 & 0.026 \\
\hline Eualus spp. & 0.41 & & 0.23 & -0.02 & & 0.00 & * & -0.30 & -0.03 & * & 0.16 & 0.017 \\
\hline Hippolyte spp. & 2.59 & * & -1.31 & 1.07 & & 0.24 & & 0.02 & -0.18 & * & -0.86 & $<0.001$ \\
\hline Processa spp. & 0.16 & & 0.01 & 0.04 & * & 0.07 & & 0.12 & -0.02 & & 0.03 & 0.317 \\
\hline Thoralus cranchii & 6.35 & & -0.30 & -0.72 & $*$ & -2.81 & $*$ & -4.56 & 2.23 & * & -1.35 & $<0.001$ \\
\hline \multicolumn{13}{|l|}{ Brachyura } \\
\hline Pilumnus spp. & 0.95 & * & 0.42 & -0.06 & * & -0.69 & * & -0.46 & 0.43 & * & -0.54 & $<0.001$ \\
\hline Pirimela denticulata & 0.09 & * & -0.11 & 0.17 & & 0.06 & & 0.09 & -0.07 & & -0.03 & 0.018 \\
\hline Xantho spp. & 1.49 & * & -0.06 & 0.59 & & 0.00 & & 0.28 & -0.07 & $*$ & 1.34 & $<0.001$ \\
\hline \multicolumn{13}{|l|}{ Anomura } \\
\hline Paguridae & 3.07 & & 0.86 & 0.30 & * & 1.65 & * & -2.69 & 1.12 & & -0.62 & $<0.001$ \\
\hline Pisidia longicornis & 11.12 & * & 5.93 & -1.60 & * & -6.78 & * & -7.61 & 2.61 & * & 3.46 & $<0.001$ \\
\hline Porcellana platychele & es 0.17 & * & -0.03 & 0.21 & & 0.09 & & 0.13 & 0.04 & * & 0.22 & $<0.001$ \\
\hline (Percent) & & $(63.6)$ & & & $(45.4)$ & & $(54.5)$ & & & $(72.7)$ & & \\
\hline
\end{tabular}

variable patterns among species. Pilumnus spp. and Pirimela denticulata had higher densities on flat rock surfaces, while Xantho spp. appeared mostly on cobbles. These patterns were consistent in adults for Pilumnus and Xantho, although in the latter a different vertical distribution pattern was observed, with juveniles located in deeper areas and adults in the low intertidal. Densities of adults of $P$. denticulata were very low $\left(<0.30\right.$ ind. $\left.\mathrm{m}^{-2}\right)$ in all habitats (Appendix 2; available at www.int-res.com/articles/ suppl/m324p173_app.pdf). Many other brachyuran species were found at low densities $(<1 \%$ of total abundance) and therefore were not included in the statistical analyses; in many of these species adults were absent (Table 1).

\section{Anomura}

Species like Pisidia longicornis, Porcellana platycheles and Galathea strigosa showed clear substrate preferences, occurring mainly on cobbles. Furthermore, $P$. longicornis and G. strigosa also had significant differences regarding depth, with preferential distribution at intermediate and deeper depths. P. longicornis maintained a similar distribution in juveniles and adults, although a slight dispersion of adults towards intertidal zones was observed. $P$. platycheles showed a differential vertical distribution of different maturity stages, with a higher proportion of adults at intertidal zones. No adults of G. strigosa were found. Regarding exposure level, G. strigosa and P. longicornis were mainly found in 
exposed areas, whereas $P$. platycheles occurred only in sheltered habitats (Table 2, Appendix 3; available at www.int-res.com/articles/suppl/m324p173_app.pdf).

The superfamily Paguridea was mainly represented by adult stages in rocky habitats, though the few juveniles found had clearer habitat preferences than adult phases (Table 2, Appendix 3).

\section{Kelp holdfasts}

Almost all taxa found on rocky bottoms occurred also on kelp holdfasts, except Eualus. Compared to other habitats, there was a less significant effect of all the factors on juvenile and adult distribution, since $42 \%$ of the models for juveniles and $25 \%$ of those for adults were not significant ( $p>0.05)$; no apparent differences among variables were observed. Furthermore, the percentages of occurrence of the different variables in the models for juveniles were lower than those obtained for rocky bottoms (Table 3). Distribution in holdfast samples for most species followed similar patterns to those on rocky bottoms regarding sampling site, depth and exposure level. However, Galathea strigosa, Porcellana platycheles, Athanas nitescens and Xantho spp., which appeared mostly on cobbles, occurred mainly on kelp holdfasts located in sheltered zones. Juveniles of $G$. strigosa appeared at relatively high densities on holdfasts (up to 4.6 ind. holdfast ${ }^{-1}$ ), although they could not be compared directly to densities in rocky samples (Appendices 1 to 3).

Generally, the proportion of adults of each species was equal (Thoralus cranchii, Pilumnus spp., Pisidia longicornis) or higher (Athanas nitescens, Hippolyte spp.) than in rocky bottom samples, with cases like Xantho for which the proportion of adults reached $92 \%$ in holdfast samples. The few species in which only juveniles appeared (Palaemon spp. and Porcellana platycheles) had very low densities on holdfasts.

Table 3. Results of GLM fitted to the distribution of the most abundant species of decapod crustaceans in kelp holdfasts in the Ria de A Coruña. Values estimated for the different levels of the variables are relative to the missing level of each one, considered as 0 level. Variables included (Incl.) in the most parsimonious models are indicated with asterisks. Percentage of models in which a variable has been included is shown; p-values indicate the significance of the most parsimonious model for each species

\begin{tabular}{|c|c|c|c|c|c|c|c|c|c|c|}
\hline \multirow[t]{3}{*}{ Species } & \multirow[t]{3}{*}{ Intercept } & \multicolumn{5}{|c|}{ Mesoscale } & \multirow{2}{*}{\multicolumn{3}{|c|}{$\begin{array}{c}\text { Microscale } \\
\text { Depth (10s m) }\end{array}$}} & \multirow[t]{3}{*}{$\mathrm{p}$} \\
\hline & & \multirow{2}{*}{\multicolumn{3}{|c|}{$\begin{array}{l}\text { Sampling station }(\mathrm{km}) \\
\text { Incl. Canide Canabal }\end{array}$}} & \multicolumn{2}{|c|}{ Wave exposure (100s m) } & & & & \\
\hline & & & & & Incl. & Exposed & Incl. & 0 & 1 & \\
\hline \multicolumn{11}{|l|}{ Juveniles } \\
\hline \multicolumn{11}{|l|}{ Caridea } \\
\hline Athanas nitescens & 9.99 & * & -4.33 & -7.42 & & 0.01 & * & -6.05 & 5.83 & 0.01 \\
\hline Hippolyte spp. & 3.00 & & -0.74 & -0.38 & & 0.14 & * & -1.35 & 1.90 & 0.04 \\
\hline Palaemon spp. & 0.07 & * & 0.13 & -0.06 & & 0.03 & & -0.04 & 0.02 & 0.17 \\
\hline Processa spp. & 0.11 & & 0.14 & 0.08 & * & -0.21 & & 0.15 & 0.25 & 0.10 \\
\hline Thoralus cranchii & 1.93 & ${ }^{*}$ & 0.49 & -1.28 & * & 0.68 & * & -1.89 & 1.51 & $<0.001$ \\
\hline \multicolumn{11}{|l|}{ Brachyura } \\
\hline Pilumnus spp. & 4.99 & & -1.00 & -1.02 & * & 1.42 & & -0.16 & 0.88 & 0.02 \\
\hline Pirimela denticulata & 0.17 & * & -0.11 & 0.22 & & 0.03 & & -0.09 & -0.04 & 0.08 \\
\hline Xantho spp. & 0.00 & & -0.01 & 0.01 & $*$ & -0.01 & & 0.00 & 0.02 & 0.31 \\
\hline \multicolumn{11}{|l|}{ Anomura } \\
\hline Galathea strigosa & 0.51 & $*$ & -0.18 & 0.35 & * & -0.18 & * & -0.17 & -0.49 & $<0.001$ \\
\hline Paguridae & 0.81 & & 0.04 & -0.02 & & -0.07 & * & -0.81 & -0.68 & $<0.001$ \\
\hline Pisidia longicornis & 1.72 & * & 1.22 & -0.64 & & 0.18 & * & -1.62 & 1.46 & $<0.001$ \\
\hline Porcellana platycheles & $S \quad 0.00$ & & -0.02 & 0.04 & * & -0.02 & & 0.03 & 0.03 & 0.14 \\
\hline (Percent) & & $(50)$ & & & $(50)$ & & $(50)$ & & & \\
\hline \multicolumn{11}{|l|}{ Adults } \\
\hline \multicolumn{11}{|l|}{ Caridea } \\
\hline Athanas nitescens & 2.41 & * & -1.52 & -2.06 & * & -0.88 & & -0.34 & 0.79 & $<0.001$ \\
\hline Hippolyte spp. & 2.52 & * & -1.18 & -0.37 & & 0.34 & * & -1.27 & -0.10 & 0.03 \\
\hline Processa spp. & -0.01 & & -0.02 & 0.03 & * & -0.02 & & 0.04 & 0.01 & 0.31 \\
\hline Thoralus cranchii & 4.68 & * & 1.48 & -3.42 & & 0.47 & * & -3.95 & 3.40 & $<0.001$ \\
\hline \multicolumn{11}{|l|}{ Brachyura } \\
\hline Pilumnus spp. & 1.49 & & -0.58 & -0.11 & * & 0.44 & & 0.61 & 0.16 & 0.06 \\
\hline Xantho spp. & 0.23 & * & -0.04 & -0.20 & & -0.13 & & 0.00 & 0.15 & 0.23 \\
\hline \multicolumn{11}{|l|}{ Anomura } \\
\hline Paguridae & 0.67 & * & 0.68 & -0.36 & & -0.11 & * & -0.63 & 0.33 & 0.01 \\
\hline Pisidia longicornis & 2.10 & & -0.06 & -0.08 & $*$ & 1.13 & ${ }^{*}$ & -1.67 & 1.27 & $<0.001$ \\
\hline (Percent) & & $(62.5)$ & & & $(50)$ & & $(50)$ & & & \\
\hline
\end{tabular}




\section{DISCUSSION}

\section{Potential nursery role of shallow habitats}

The higher proportion of juveniles found for most species suggests that the sampled habitats fulfil the requirements of a nursery habitat. Nevertheless, these habitats do not serve as a nursery for all decapods, according to the criteria in Beck et al. (2001). First, the high juvenile densities found may be explained by the high levels of larval settlement taking place during summer in temperate latitudes (Pfister 1997). In contrast, the nursery role concept is only applicable to those species whose life-history strategies display a segregation between juvenile and adult habitats, which did not occur in several species in the study area.

Some species (e.g. Porcellana platycheles, Pisidia longicornis, Pilumnus spp.) lacked a spatial segregation between juvenile and adult phases at the studied scales. Other species (e.g. Athanas nitescens, Eualus spp., Xantho spp.) exhibited spatial segregation, with juveniles occurring in a subset of adult habitats. However, the observed ontogenetic changes in distribution may be due to dispersal, which could be due to density-dependent factors and to a wider stress tolerance range rather than to changes in habitat requirements (Moksnes 2004). Absence of adults of Palaemon shrimps in the samples does not imply habitat segregation, since their high mobility may have allowed them to avoid the sampling device.

The nursery role hypothesis seems appropriate for the larger decapod species, where the greater size differences between juveniles and adults probably lead to differences in habitat use. The proportion of adults decreased dramatically for those species with a large size at maturity, including Galathea strigosa and several infrequent species of large crabs for which adults were absent (e.g. Cancer pagurus, Maja brachydactyla). Since there is evidence of adult presence at deeper depths (Hayward et al. 1995, Fariña et al. 1997, Freire et al. 2002, Gonzalez-Gurriaran et al. 2002), we hypothesise that these shallow habitats play an important nursery role for these larger species. For smaller species, the sampled habitats were apparently suitable for juveniles and adults, though this lack of habitat segregation may have been due to a low sampling resolution at the small spatial scale. The differential ontogenetic distribution found in pagurids also suggests a potential nursery role of sandy bottoms for this group. Further studies must test these hypotheses, taking into account juvenile survival, growth and movement to adult habitats (see Beck et al. 2001, Gillanders et al. 2003). Finally, the results obtained for Thoralus cranchii, a species in which adults were more abundant than juveniles, might be due to intercohort variability in recruitment, since no spatial segregation was observed.

\section{Effects of environmental variables on distribution patterns}

The strong mesoscale variation in juvenile distribution may have been due to differential larval input (Wahle \& Incze 1997, Wing et al. 1998) along the main axis of the coastal embayment. The hydrodynamic pattern of the Ria de A Coruña divides it into 2 parts (Montero et al. 1997). The inner area is dominated by a clockwise eddy, which may limit larval dispersion and input, depending on tidal cycle, whilst the outer zone is more influenced by oceanic circulation and can receive a greater influx of larvae. This pattern may have been responsible for the higher densities of juveniles at the external site for most species, since other processes, such as active habitat selection and post-settlement migration, seem less probable given the large spatial scale. In a few cases (e.g. Athanas nitescens) the pattern differs, probably due to the association of the larval input with favourable tidal conditions or to larval retention processes. Nevertheless, a great range of post-settlement processes like differential mortality, dispersion and ontogenetic habitat shifts may explain the higher mesoscale homogeneity in adult distribution. However, there are some exceptions (e.g. Pisidia longicornis, Porcellana platycheles) in which adult populations could be strongly limited by juvenile distribution, i.e. by larval dispersion and settlement processes (Fernandez et al. 1990).

The major microscale variable affecting differential spatial distribution was substrate type, though wave exposure and depth also influence distribution patterns to a lesser extent. Some species showed preferences for sheltered areas where physical stress is minimised (Processa spp., Pirimela denticulata, Porcellana platycheles); only species occurring in cobbles seemed to prefer exposed areas. This limited effect could in part be explained by the small variation in wave exposure in the study area at the selected spatial scales. In general, juveniles appeared in deeper zones, where predation risk may be higher but wave disturbance is minimised. This observation is in contrast with observations of other systems, where predation on crabs is lower in shallow habitats (Ruiz et al. 1993, Dittel et al. 1995). However, these studies focused on single species in a restricted set of habitat types, characterised by a lack of 3-dimensional structure to be used as refuge. Our comparative inter-specific approach and the study of a wide range of habitats allowed us to detect a different pattern that seemed to be consistent among several decapod species. In our system, early benthic stages may be more vulnerable to physical stress than adults, thus minimising it by inhabiting deeper areas. The characteristically high predation rates in deeper zones could be avoided by 
using microrefuges, available only for small individuals, as has been observed in American lobster (Wahle \& Steneck 1991). Adults may be less vulnerable to both factors, thus dispersing in a wider depth range.

Generally, substrates with a complex 3-dimensional structure are suitable for settlement and survival of early stages of decapods (Wahle \& Steneck 1991, Moksnes 2002, Heck et al. 2003), while the poor structure of sandy bottoms does not fulfil the habitat requirements of most taxa. Early stages of hermit crabs were associated with this habitat because of their dependence on the use of empty gastropod shells (Barnes \& Arnold 2001, De Grave \& Barnes 2001), which occur mainly in soft sediments. This behaviour allows them to avoid predation in the absence of 3dimensional shelter. Strong competition for this resource among different pagurid species could lead to the complex distribution patterns observed and would explain the presence of adults in a great variety of sandy and rocky habitats.

In the study area the different rocky substrate types constituted nearby patches, among which movement would be easy for shrimps and to a lesser extent for brachyuran and anomuran crabs. Cobble substrates are considered to be valuable nurseries, due to their abundance in a wide range of subtidal ecosystems and to their interstitial nature, which provides shelter for many species, particularly benthic decapods (Wahle \& Incze 1997, Linnane et al. 2002). The nursery function of flat rock surfaces has been less studied, but the algal communities may also provide a 3-dimensional structure suitable for benthic decapods, especially for highly mobile species, as has been observed in seaweed-covered soft bottoms (Lopez de la Rosa et al. 2002). Differential distribution between habitats was related to anatomical and behavioural adaptations. Species found mostly in flat surfaces show swimming activity and cryptic adaptations to mimic seaweed, as in Hippolyte spp. Conversely, Athanas nitescens shows relatively little active swimming behaviour, which may lead them to search for shelter in cobbles and crevices.

Anomuran crabs, which demonstrated a preference for cobble substrates, display adaptations for inhabiting interstitial spaces (i.e. depressed bodies and flattened or elongated chelae). Porcellana platycheles occurred in the lower intertidal and upper subtidal zones with rocks and boulders, which is consistent with patterns described previously (Stevcic 1985). This distribution may be due to their non-territorial behaviour and reduced activity associated with microphagous feeding (Stevcic 1985). Conversely, Pisidia longicornis had a wider distribution among different substrates, although the highest abundances occurred in cobbles. This is consistent with its abundance on rocky bottoms along the eastern Atlantic coast, where it appears in a great variety of ecosystems, usually in cobble and gravel substrates (Sampedro et al. 1997, Robinson \& Tully 2000, Linnane et al. 2002).

The patterns in brachyuran crabs - Pilumnus spp. and Pirimela denticulata on rock surfaces and Xantho spp. on cobbles - appear to be similar for juveniles and adults. This may be related to their more restricted mobility with respect to carideans. However, many of the brachyuran species were found at low densities, and their ontogenic changes in distribution might differ from the patterns described above.

Focusing on kelp holdfasts, the ontogenic distribution patterns observed suggest that these habitats are used as a temporary shelter (e.g. against predation, during mating) rather than a permanent habitat or a settlement and nursery substrate. The influence of environmental stress could be attenuated inside kelp holdfasts, allowing the presence of many typically cobble-inhabiting species inside them.

\section{Processes determining habitat use}

Patterns of habitat use could be explained by the underlying processes acting at different spatial scales on juvenile and adult stages. While larval transport may account for mesoscale distribution, microscale patterns could be determined by complex interactions among different processes.

All the species showed a differential distribution among habitats, at least in juvenile stages. This can be explained by habitat selection at settlement or in early benthic stages or by early differential mortality. Our methodology did not allow us to discriminate between these processes. To assess the relative importance of each mechanism, it will be necessary to carry out complementary field and laboratory experiments.

Ontogenetic habitat shifts are probably the major process acting on species with complete segregation or where juveniles occupy a subset of adult areas. Conversely, no migration or dispersion of adult phases would be acting in those species with limited spatial segregation. Small-scale dispersal could result in a wider distribution of adults without habitat segregation between juveniles and adults. Differential mortality may interact with these processes, creating more complex patterns where the individual effects of each process are difficult to discriminate.

Determining the nursery role of these shallow habitats will require more accurate studies focused on identifying areas that fulfil the major requirements of a nursery habitat, specifically larval input, factors that promote juvenile survival and growth, and the resulting contribution to the population. 
Acknowledgements. Financial support for this study was given by the Conselleria de Educacion e Ordenacion Universitaria of the Xunta de Galicia (Grant XUGA10301B97) and the Spanish Ministerio de Ciencia y Tecnologia (Grants DIMEPIC, REN2000-0446MAR, and ECOSOST, REN200304816). The authors thank P. Sampedro, who helped in the field work, and E. Godinez-Dominguez for his assistance in data analyses. We also thank the anonymous referees who improved the manuscript with their suggestions.

\section{LITERATURE CITED}

Barnes DKA, Arnold RJ (2001) Ecology of subtropical hermit crabs in SW Madagascar: cluster structure and function. Mar Biol 139:463-474

Beck MW, Heck KL, Able KW, Childers DL and 9 others (2001) The identification, conservation, and management of estuarine and marine nurseries for fish and invertebrates. Bioscience 51:633-641

Benvenuto C, Gherardi F (2001) Population structure and shell use in hermit crab, Clibanarius erithropus: a comparison between Mediterranean and Atlantic shores. J Mar Biol Assoc UK 81:77-84

Bertini G, Fransozo A (1999) Relative growth of Petrochirus diogenes (Linnaeus, 1758) (Crustacea, Anomura, Diogenidae) in the Ubatuba Region, Sao Paulo, Brazil. Rev Bras Biol 59:617-625

Caddy JF (ed) (1989) Marine invertebrate fisheries: their assessment and management. John Wiley \& Sons, New York

Cosme de Aviles A, Prego R (1995) Caracteristicas generales de la Ria de La Coruña y su cuenca fluvial. Monogr Quim Oceanogr 2:25-45

De Grave S, Barnes DKA (2001) Ecology of tropical hermit crabs (Crustacea Decapoda) at Quirimba Island, Mozambique: a mulitvariate assemblage perspective. Trop Zool 14:197-209

Dittel AI, Hines AH, Ruiz GM, Ruffin KK (1995) Effects of shallow water refuge on behaviour and density-dependent mortality of juvenile blue crabs in Chesapeake Bay. Bull Mar Sci 57:902-916

Fariña AC, Freire J, Gonzalez-Gurriaran E (1997) Megabenthic decapod crustacean assemblages on the Galician continental shelf and upper slope. Mar Biol 127:419-434

Fernandez L, Gonzalez-Gurriaran E, Freire J, Muiño R (1990) Abundancia y distribucion de Pisidia longicornis (Linnaeus, 1767) (Decapoda, Anomura) en relacion con la dinamica del cultivo de mejillon en la Ria de Arousa (Galicia, NW España). Bol R Soc Esp Hist Nat Biol 86:181-193

Freire J, Bernardez C, Corgos A, Fernandez L, GonzalezGurriaran E, Sampedro MP, Verisimo P (2002) Management strategies for sustainable invertebrate fisheries in coastal ecosystems of Galicia (NW Spain). Aquat Ecol 36: 41-50

Gillanders BM, Able KW, Brown JA, Eggleston DB, Sheridan PF (2003) Evidence of connectivity between juvenile and adult habitats for mobile marine invertebrates. Mar Ecol Prog Ser 247:281-295

Gonzalez-Gurriaran E, Mendez M (1986) Crustaceos decapodos das costas de Galicia. I. Brachyura. Cuadernos da Area de Ciencias Biologicas, Seminario de Estudos Galegos, Vol 2, 2nd edn. Ediciones do Castro, A Coruña

Gonzalez-Gurriaran E, Freire J, Bernardez C (2002) Migratory patterns of female spider crabs Maja squinado detected using electronic tags and telemetry. J Crustac Biol 22:91-97
Hayward PJ, Isaac MJ, Makings P, Moyse J, Naylor E, Smaldon G (1995) Crustaceans (Phylum Crustacea). In: Hayward PJ, Ryland JS (eds) Handbook of the marine fauna of north-west Europe. Oxford University Press, p 289-461

Heck KL Jr, Hays G, Orth RJ (2003) Critical evaluation of the nursery role hypothesis for seagrass meadows. Mar Ecol Prog Ser 253:123-136

Ingle RW (1996) Shallow-water crabs. In: Barnes RSK, Crothers JH (eds) Synopses of the British fauna, No. 25. The Linnean Society of London and The Estuarine and Coastal Sciences Association, London

Linnane A, Ball B, Munday B, Browne R, Mercer JP (2002) Faunal description of an Irish cobble site using airlift suction sampling. Biol Environ Proc R Ir Acad B 103:41-48

Lopez de la Rosa I, Garcia Raso JE, Rodriguez A (2002) Evolution of a decapod community (Crustacea) of shallow soft bottoms with seaweeds from southern Europe. J Mar Biol Assoc UK 82:85-95

Moksnes PO (2002) The relative importance of habitatspecific settlement, predation and juvenile dispersal for distribution and abundance of young juvenile shore crabs Carcinus maenas. J Exp Mar Biol Ecol 271:41-73

Moksnes PO (2004) Interference competition for space in nursery habitats: density-dependent effects on growth and dispersal in juvenile shore crabs Carcinus maenas. Mar Ecol Prog Ser 281:181-191

Moksnes PO, Hedvall O, Reinwald T (2003) Settlement behaviour in shore crabs Carcinus maenas: Why do postlarvae emigrate from nursery habitats? Mar Ecol Prog Ser 250:215-230

Montero P, Prego R, Gomez-Gesteira M, Neves R, Taboada JJ, Perez-Villar V (1997) Aplicacion de un modelo 2D al transporte de particulas en la Bahia de A Coruña. In: Prego R, Fernandez JM (eds) Procesos biogeoquimicos en sistemas costeros hispano-lusos. Excma Diputacion Provincial de Pontevedra, p 131-136

Oh CW, Hartnoll RG (1999) Size at sexual maturity, reproductive output, and seasonal reproduction of Philocheras trispinosus (Decapoda) in Port Erin Bay, Isle of Man. J Crustac Biol 18:252-259

Orensanz JM, Jamieson GS (1998) The analysis of concentration and crowding in shellfish research. In: Jamieson GS, Campbell A (eds) Proceedings of the North Pacific symposium on invertebrate stock assessment and management. Can Spec Publ Fish Aquat Sci 125:143-157

Palma AT, Steneck RS, Wilson CJ (1999) Settlement-driven, multiscale demographic patterns of large benthic decapods in the Gulf of Maine. J Exp Mar Biol Ecol 241: 107-136

Paula J, Dray T, Queiroga H (2001) Interaction of offshore and inshore processes controlling settlement of brachyuran megalopae in Saco mangrove creek, Inhaca Island (South Mozambique). Mar Ecol Prog Ser 215:251-260

Pfister CA (1997) Demographic consequences of within-year variation in recruitment. Mar Ecol Prog Ser 153:229-238

Pile AJ, Lipcius RJ, Van Montfrans J, Orth RJ (1996) Densitydependent settler-recruit-juvenile relationships in blue crabs. Ecol Monogr 66:277-300

Robinson M, Tully O (2000) Spatial variability in decapod community structure and recruitment in subtidal habitats. Mar Ecol Prog Ser 194:133-141

Roughgarden J, Gaines JS, Possingham H (1988) Recruitment dynamics in complex life cycles. Science 241:1460-1466

Ruiz GM, Hines AH, Posey MH (1993) Shallow water as a refuge habitat for fish and crustaceans in non-vegetated estuaries: an example from Chesapeake Bay. Mar Ecol Prog Ser 99:1-16 
Sampedro MP, Fernandez L, Freire J, Gonzalez-Gurriaran E (1997) Fecundity and reproductive output of Pisidia longicornis (Decapoda, Anomura) in the Ria de Arousa (Galicia, NW Spain). Crustaceana 70:95-110

Squires HJ (1990) Decapod Crustacea of the Atlantic coast of Canada. Can Bull Fish Aquat Sci 221:1-532

Squires HJ, Ennis GP, Dawe G (2000) On biology of the shrimp Eualus pusiolus (Kroyer, 1841) (Crustacea, Decapoda) at St. Chad's, Newfoundland. Sci Counc Stud NAFO 33:1-10

Stevcic Z (1985) Autoecological investigations of the porcelain crab Porcellana platycheles (Pennant) (Decapoda, Anomura) in the Rovijn area (northern Adriatic). Crustaceana 55:242-252

Stoner AW (2003) What constitutes essential nursery habitat for a marine species? A case study of habitat form and function for queen conch. Mar Ecol Prog Ser 257: 275-289

Van Montfrans J, Ryer CH, Orth RJ (2003) Substrate selection

Editorial responsibility: Otto Kinne (Editor-in-Chief), Oldendorf/Luhe, Germany by blue crab Callinectes sapidus megalopae and first juvenile instars. Mar Ecol Prog Ser 260:209-217

Wahle RA, Incze LS (1997) Pre- and post-settlement in recruitment of the American lobster. J Exp Mar Biol Ecol 217:179-207

Wahle RA, Steneck RS (1991) Recruitment habitats and nursery grounds of the American lobster Homarus americanus: a demographic bottleneck? Mar Ecol Prog Ser 69:231-243

Williams AB (1984) Shrimps, lobsters and crabs of the Atlantic coast of the eastern United States, Maine to Florida. Smithsonian Institution Press, Washington, DC

Wing SR, Botsford LW, Quinn JF (1998) The impact of coastal circulation on the spatial distribution of invertebrate recruitment, with implications for management. In: Jamieson GS, Campbell A (eds) Proceedings of the North Pacific symposium on invertebrate stock assessment and management. Can Spec Publ Fish Aquat Sci 125:285-294

Zariquiey Alvarez R (1968) Crustaceos decapodos ibericos. Invest Pesq (Spain) 32:1-510

Submitted: August 5, 2005; Accepted: March 23, 2006 Proofs received from author(s): September 27, 2006 